\title{
Working
}

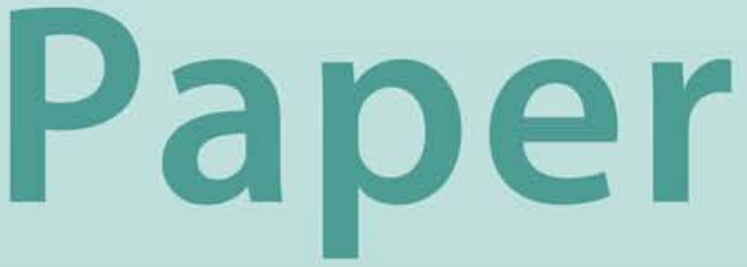


The Spillover Effects of the Global Crisis on Economic Activity in MENA Emerging Market Countries-An Analysis Using the Financial Stress Index

\author{
Kenji Moriyama
}




\title{
IMF Working Paper
}

Middle East and Central Asia Department

\section{The Spillover Effects of the Global Crisis on Economic Activity in MENA Emerging Market Countries-An Analysis Using the Financial Stress Index}

\author{
Prepared by Kenji Moriyama
}

Authorized for distribution by Hassan Al-Atrash

January 2010

\begin{abstract}
This Working Paper should not be reported as representing the views of the IMF. The views expressed in this Working Paper are those of the author(s) and do not necessarily represent those of the IMF or IMF policy. Working Papers describe research in progress by the author(s) and are published to elicit comments and to further debate.

The estimated spillover of the global crisis to emerging market (EM) economies in the Middle East and North Africa (MENA) indicates that nearly two-thirds of the increased financial stress in MENA EM countries after the Lehman shock is attributable to direct or indirect spillovers of financial stress in advanced economies. Moreover, the estimated models suggest that the increased financial stress and slowdown in economic activity in advanced economies can explain about half of the drop in real GDP growth in MENA EM countries after the Lehman shock.
\end{abstract}

JEL Classification Numbers:C23, C43, E66.

Keywords: Spillover, financial stress, emerging market.

Author's E-Mail Address:kmoriyama@,imf.org 


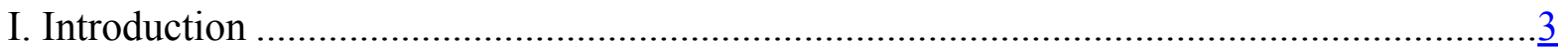

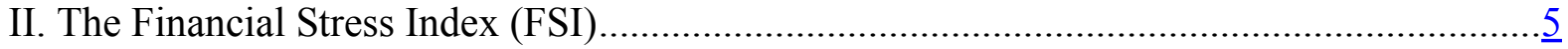

III. Spillovers of Financial Stress to the MENA Region-Common Time-Varying Component Analysis ............................................................................................ 6

IV. Impact of Financial Stress and Trade Partners' Economic Activity on Economic Activity in MENA EM countries —Panel GMM Analysis .......................................

V. Comparison of Economic Activity Implied by the Estimated Model with

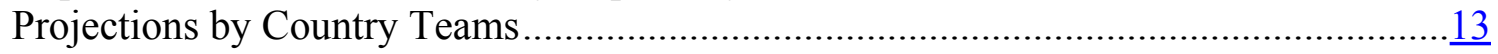

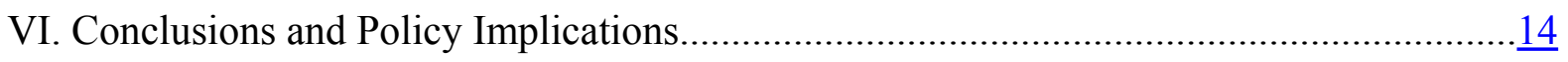

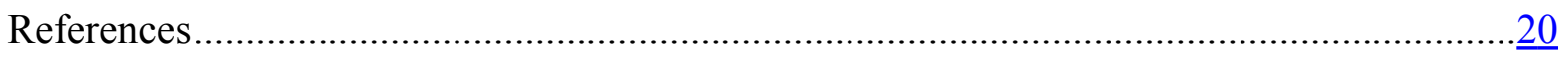

Text Tables

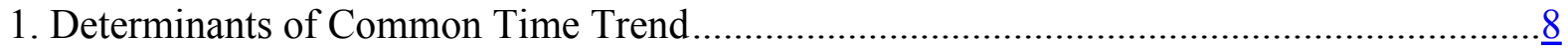

2. Financial Stress in MENA EM Countries, Decomposition …........................................ $\underline{9}$

3. Estimated Impact of Financial Stress and Trade Partners' Growth on Real GDP Growth in MENA EM Countries

4. Decomposition of Real GDP Growth in MENA EM Countries ...................................13

5. Real GDP Growth in MENA EM Countries ..............................................................14

Figures

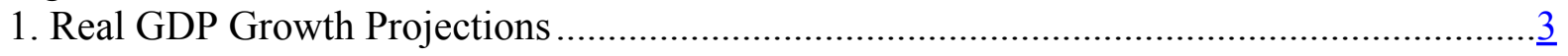

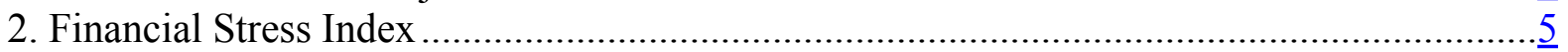

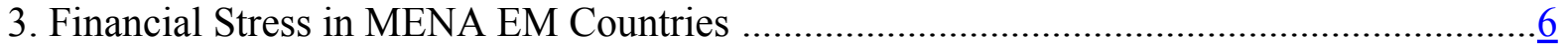

4. Financial Stress in GCC Countries ….....................................................................

5. Common Time Component in MENA EM Countries and Financial Stress in Advanced Economies ..........................................................................................

6. Common Time Component in GCC Countries and Financial Stress in Advanced

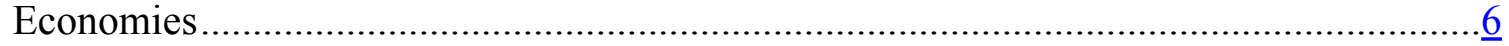

7. Decomposition of Financial Stress in GCC Countries .................................................. $\frac{9}{9}$

8. Decomposition of Financial Stress in MENA EM Countries ............................................ $\frac{9}{2}$

9. Decomposition of Real GDP Growth in MENA EM Countries .....................................12

Appendices

I. Technical Description of the Financial Stress Index (FSI) ......................................15

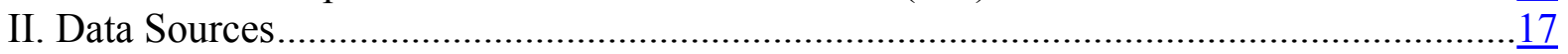

III. Panel GMM Estimators....................................................................................... 18

IV. Relationship Between Economic Activity in Trade Partners of MENA EM Countries and Advanced Economies - Common Time-Varying Component Analysis.................19

Appendix Tables

A-1. Determinants of Common Time Trend................................................................... 19

A-2. Decomposition of Trade Partners' Real GDP Growth in MENA EM Countries ............19 


\section{INTRODUCTION}

1. The global financial crisis has significantly weakened world economic activity. As a result, world real GDP growth projections have been revised downward from 4 percent to below 1 percent for 2009, and from 5 percent to 3 percent for 2010 , respectively, in the IMF's Spring 2008 and Fall 2009 World Economic Outlook (WEO) exercise. Although emerging market (EM) countries in the Middle East and North Africa (MENA) region ${ }^{1}$ were relatively insulated from the impact of the crisis at the outset - given their limited exposure to structured financial products and low levels of financial integrationthe global slowdown has begun to affect their economic activity. As such, projections of real GDP growth in MENA

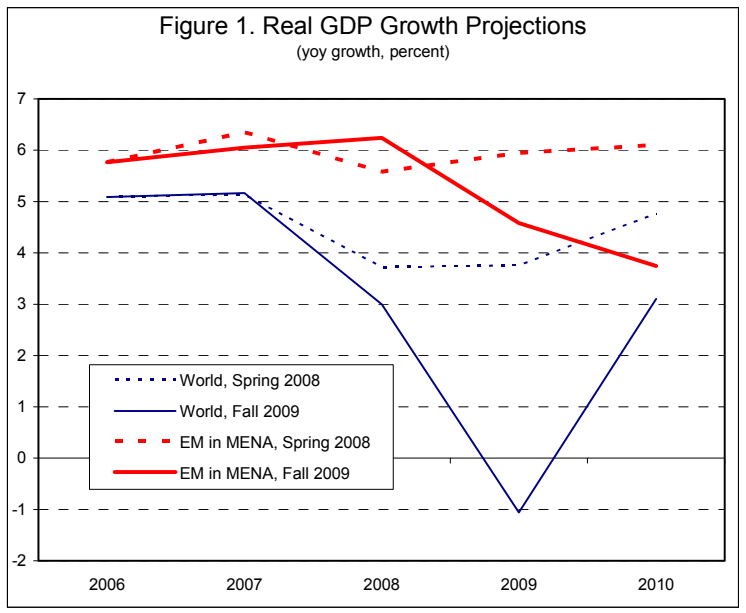
EM countries in the Regional Economic Outlook (REO) have also been revised downward from 6 percent to 4 percent for 2009 and 2010, respectively (Figure 1).

2. How has the crisis in advanced economies affected MENA EM countries? How severe was the spillover of the crisis in advanced economies to EM countries?

3. Such spillovers can take place through (i) a collapse in export demand for goods and services, (ii) a decline in remittance inflows, and (iii) a sudden stop of capital inflows (foreign direct investment, portfolio inflows, and bank loans) (Ghosh et al. 2009). Their impact can be measured by estimating the response (elasticity) of real GDP growth to trade partners' economic activity and financial stress in advanced economies. It is not a simple task, however, to measure the extent of resultant financial stress.

4. While there has been much analysis of the spillover effects of the global crisis to emerging market economies (for example, Mühleisen et al. 2008; Beirne et al. 2008; Galesi and Sgherri 2009; and Frank and Hesse 2009), there has been no study of these spillovers to MENA EM countries.

5. As such, and in light of the important policy implications of the impact of the crisis on the region, this paper looks at the following five interrelated questions:

- Is there a measure of financial stress that helps estimate the size of spillovers of the financial crisis?

\footnotetext{
${ }^{1}$ Egypt, Jordan, Lebanon, Morocco, Pakistan, and Tunisia.
} 
- Was increased financial stress in advanced economies transmitted to MENA EM countries after the Lehman shock?

- Did increased financial stress and a slowdown in trade partners' real GDP growth affect real GDP growth in MENA EM countries after the Lehman shock?

- $\quad$ Are the baseline growth projections of the Fall 2009 WEO and REO exercise consistent with the projections derived from the estimated model?

- What are the policy implications of the estimates in this paper?

6. The financial stress index (FSI) for emerging market economies presented in IMF $(2009)^{2}$ summarizes a number of some channels/factors transmitting the spillovers of the global crisis to MENA EM countries. It consists of an exchange market pressure index and four market-based price indicators (sovereign spreads, the banking sector " $\beta$ ", stock market returns, and stock market volatility), where each component is normalized. A rising FSI indicates increased financial stress in an economy.

7. This paper uses the FSI to estimate (i) the spillover of increased financial stress from advanced economies to MENA EM countries, and (ii) the impact of higher financial stress and lower economic activity in trade partners on economic activity in MENA EM countries. The estimated models decompose financial stress and economic activity in MENA EM countries into factors that are considered to transmit the negative impact of the global crisis, helping quantify the sources of the slowdown in economic activity after the Lehman shock.

8. The paper's main contribution is to quantify the impact of the global financial crisis on economic activity in MENA EM countries. The estimated models suggest that nearly twothirds of increased financial stress in MENA EM countries after the Lehman shock is attributable to direct or indirect spillovers of financial stress in advanced economies. Also, a simple back-of-the-envelope calculation with the estimated models indicates that increased financial stress and slowdown in economic activity in advanced economies can explain about half of the decline in real GDP growth in MENA EM countries after the Lehman shock. Moreover, the baseline projections of real GDP growth in the Fall 2009 WEO and REO exercise appear to be in the same ballpark as the projections derived from the model estimated in the paper.

9. The paper is organized as follows: Section II introduces the FSI and presents its developments in MENA EM and Gulf Cooperation Council (GCC) countries, following the method presented in IMF (2009). Section III estimates the spillover of financial stress from advanced economies to MENA EM countries using the common time-varying component analysis. Section IV investigates the spillover of the financial crisis to economic activity in the MENA EM countries using the Generalized Method of Moments (GMM). Section V compares the real GDP growth implied by the estimated model with the projections in the Fall 2009 WEO and REO exercise. Section VI briefly discusses implications and concludes.

\footnotetext{
2 "How Linkages Fuel the Fire: The Transmission of Financial Stress from Advanced to Emerging Economies."
} 


\section{The FinanCIAL Stress IndeX (FSI)}

10. The FSI for emerging market economies presented in IMF (2009) summarizes some of the main channels/factors transmitting the spillovers of the global crisis to MENA EM countries. The FSI is useful in that it can save the degree of freedom in models used for empirical analysis - particularly for empirical studies of emerging countries that usually do not have long-term consistent data. The index consists of an exchange market pressure index (EMPI) and four market-based price indicators (sovereign spreads, the banking sector " $\beta$," stock market returns, and stock market volatility), where each component is normalized. A rising FSI indicates increased financial stress in an economy (Appendix I provides a technical description of the FSI; Appendix II presents data sources).

11. Figure 2 plots estimated FSIs covering January 2001 to March 2009 for advanced economies (taken from Cardarelli et al (2009)), as well as for MENA EM countries and GCC countries, where each country-by-country FSI is simply averaged over countries in each group. The figure suggests that:

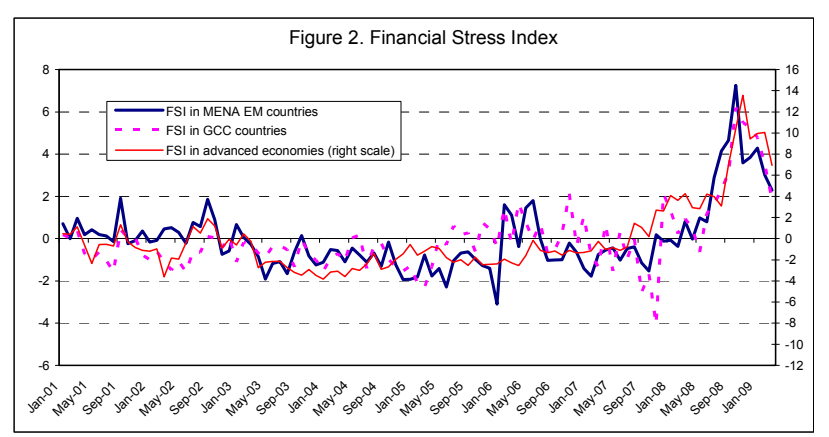

- $\quad$ Financial stress has been relatively mild. Through mid-2007, FSIs were close to or below zero, on average, except during the period of the sharp stock market price correction in the MENA region in early 2006;

- $\quad$ Financial stress in advanced economies started to increase after the third quarter of 2007, while financial stress in the MENA region remained mild until the second quarter of 2008; and

- $\quad$ Financial stress increased dramatically after the second quarter of 2008 in all three areas.

12. Figures 3 and 4 present the estimated FSIs for MENA EM countries and GCC countries. The figures suggest that:

- $\quad$ Financial stress in MENA EM and GCC countries was relatively mild, on average, until the second quarter of 2008, except for the period of the stock market price correction in the MENA region in the first half of 2006;

- $\quad$ Financial conditions in MENA EM countries were favorable during 2005-07, supported mainly by low spreads;

- A sharp decline in stock market prices, greater stock market return volatility, and increased spreads contributed to increased financial stress in both MENA EM countries and GCC countries after the second quarter of 2008; and 
- $\quad$ Financial stress reached its peak in the fourth quarter of 2008 and subsequently declined sharply: in April 2009, financial stress declined to 1 for MENA EM countries and to 2 for GCC countries.
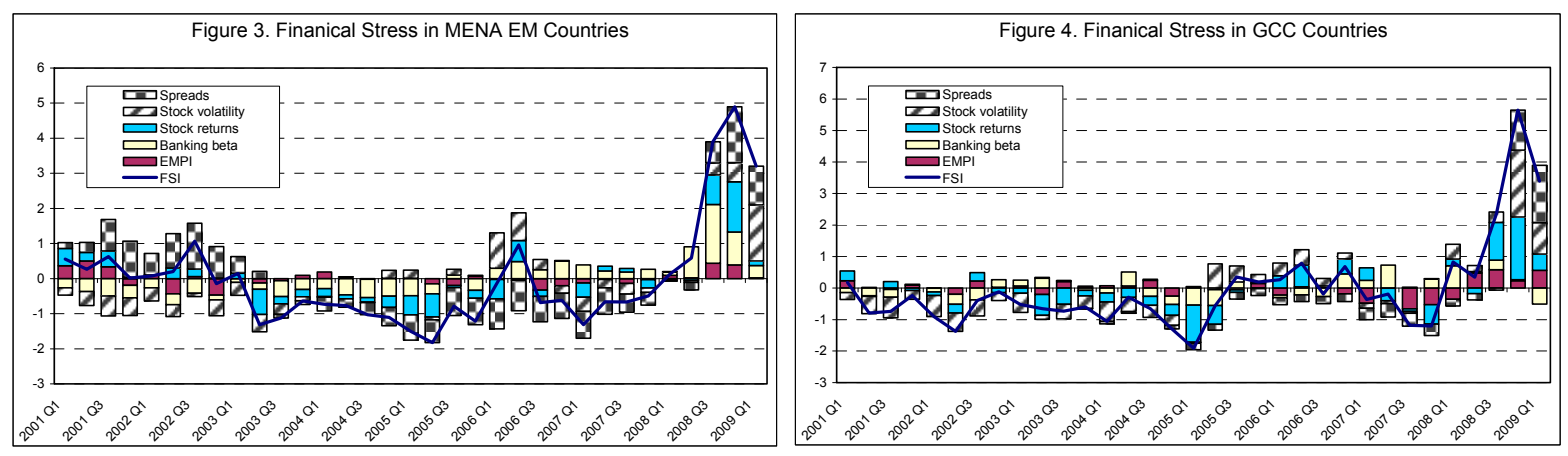

\section{SPillovers of Financial Stress to the MENA Region-Common Time- VARYING COMPONENT ANALYSIS}

13. This section estimates the spillovers of financial stress from advanced economies to MENA EM countries and GCC countries using the common time-varying component method, following the specification in Chapter 4 in IMF (2009). As a first step, monthly panel data for MENA EM countries and GCC is separately regressed on country-specific fixed effects $\left(\alpha_{i}\right)$ and time dummies, where $M_{t}$ denotes a dummy variable for month $t$ in the panel data:

$$
F S I_{i t}=\alpha_{i}+\sum_{t} \varphi_{t} M_{t}+\varepsilon_{i t}
$$

The estimated series of coefficients $\left\{\varphi_{t}\right\}$ measure the common time-varying element in FSI in MENA EM countries and GCC countries, respectively. This component has significant explanatory power, accounting for 40 percent of overall variation in financial stress in MENA EM countries and 50 percent of variation in GCC countries despite monthly (high-frequency) data with a lot of noise in general (Figures 5 and 6).
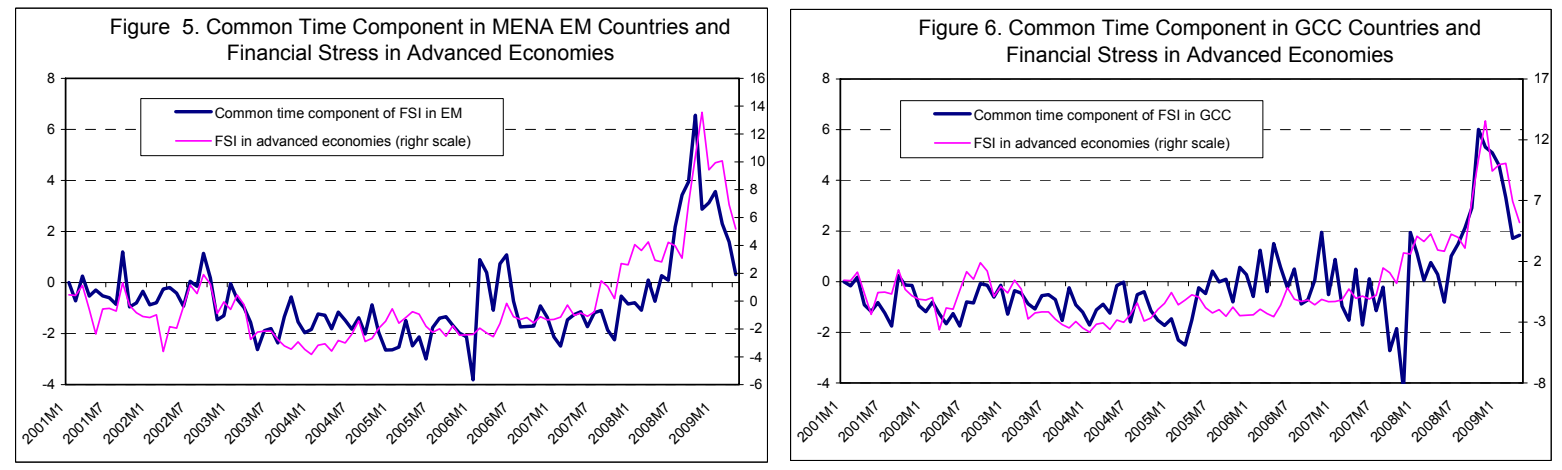
14. In a second step, the estimated series of coefficients is regressed on financial stress in advanced economies and other global factors, such as production in advanced economies, oil prices, and commodity prices:

$$
\varphi_{t}=\alpha+\beta F S I_{t}^{A d v}+\sum_{k} \gamma_{k} G F_{t}^{k}+\varepsilon_{t}
$$

where $F S I_{t}^{A d v}$ is financial stress in advanced economies and $G F$ denotes global factors, including monthly data of production change (12-month change) in advanced economies, oil prices (12-month change) and aggregate commodity prices (12-month change), following the specification in IMF (2009). As an alternative, financial stress in GCC countries is included in the regression for MENA EM countries, in an attempt to detect the transmission of financial stress from GCC countries.

15. Since the estimated residuals of the baseline model are serially autocorrelated, the model is estimated in two ways to eliminate serial correlation: (i) by inserting a lag of coefficient (time-varying component: $\varphi_{t-1}$ ) and (ii) using the Cochrane-Orcutt method. In any specifications, all variables in the right hand side of the model are assumed to be exogenous. This assumption is reasonable given the relative size of external assets of GCC countries and MENA EM countries to advanced economies, and MENA EM countries to GCC countries, ${ }^{3}$ in addition to the assumption that the MENA region is a small, open economy.

16. Table 1 summarizes the results. In sum, the model with a lag of common timevarying component has a good explanatory power, with the adjusted $R^{2}$ close to 0.7 for MENA EM countries and over 0.6 for GCC countries, suggesting that financial stress in advanced economies plays an important role in predicting financial stress in MENA EM countries and GCC countries:

- $\quad$ Financial stress in advanced economies has a statistically significant impact on the time-varying component in all specifications in both MENA EM countries and GCC countries - a 1 point permanent increase in financial stress in advanced economies would increase financial stress in MENA EM and GCC countries by $0.2-0.3$ points and $0.3-0.4$ points, respectively; and

- $\quad$ Financial stress in GCC countries has significant explanatory power for the timevarying component of MENA EM countries, suggesting that some of the recent increase in financial stress in MENA EM countries is attributable to increased financial stress in the Gulf area (Specifications (2) and (4)). The observation may imply an indirect route of transmitting financial stress from advanced economies to MENA EM countries through GCC countries, since financial stress in advanced economies has a significant explanatory power for financial stress in GCC countries (Specifications (5) and(6)).

\footnotetext{
${ }^{3}$ While data on external assets position are not available for some MENA countries, the accumulated current account balance since 1968 (the latest year for which data is available) - a possible proxy for the external assets position - amounts to US\$ -200 billion for EM countries and US\$ 1,400 billion for GCC countries, suggesting that the causality of financial stress from EM countries to GCC countries is limited.
} 
Table 1. Determinants of Common Time Trend ${ }^{1 /}$

\begin{tabular}{|c|c|c|c|c|c|c|c|}
\hline & \multicolumn{5}{|c|}{ MENA Emerging Market Countries ${ }^{2 /}$} & \multicolumn{2}{|c|}{ GCC Countries } \\
\hline & (1) & & & (3) & (4) & (5) & (6) \\
\hline $\begin{array}{l}\text { Autoregressive part of common component } \\
\qquad(-1)\end{array}$ & $\begin{array}{c}0.426 \\
(4.16)^{* *}\end{array}$ & $\begin{array}{l}0.370 \\
(3.56)^{* *}\end{array}$ & & & & $\begin{array}{c}0.329 \\
(3.39)^{* *}\end{array}$ & \\
\hline FSI in advanced economies & $\begin{array}{l}0.160 \\
(3.15)^{* *}\end{array}$ & $\begin{array}{c}0.119 \\
(2.21)^{*}\end{array}$ & $\begin{array}{l}0.334 \\
(6.84)^{\star *}\end{array}$ & $\begin{array}{c}0.290 \\
(5.22)^{\star *}\end{array}$ & $\begin{array}{c}0.226 \\
(3.83)^{* *}\end{array}$ & $\begin{array}{l}0.223 \\
(4.44)^{* *}\end{array}$ & $\begin{array}{c}0.294 \\
(5.16)^{* *}\end{array}$ \\
\hline FSI in GCC countries & & $\begin{array}{c}0.193 \\
(2.11)^{*}\end{array}$ & & & $\begin{array}{l}0.221 \\
(2.43)^{*}\end{array}$ & & \\
\hline Production in advanced economies & $\begin{array}{l}-0.107 \\
(-2.05)^{*}\end{array}$ & $\begin{array}{l}-0.091 \\
(-1.76)\end{array}$ & & $\begin{array}{l}-0.114 \\
(-1.83)\end{array}$ & $\begin{array}{l}-0.098 \\
(-1.62)\end{array}$ & $\begin{array}{l}-0.058 \\
(-1.00)\end{array}$ & $\begin{array}{l}-0.097 \\
(-1.47)\end{array}$ \\
\hline Oil prices & $\begin{array}{l}-0.028 \\
(-1.86)\end{array}$ & $\begin{array}{l}-0.019 \\
(-1.20)\end{array}$ & & $\begin{array}{l}-0.033 \\
(-1.54)\end{array}$ & $\begin{array}{l}-0.023 \\
(-1.08)\end{array}$ & $\begin{array}{l}-0.040 \\
(-2.33)^{*}\end{array}$ & $\begin{array}{l}-0.056 \\
(-2.55)^{*}\end{array}$ \\
\hline Commodity prices & $\begin{array}{c}0.056 \\
(2.11)^{*}\end{array}$ & $\begin{array}{l}0.039 \\
(1.46)\end{array}$ & & $\begin{array}{l}0.060 \\
(1.59)\end{array}$ & $\begin{array}{l}0.043 \\
(1.17)\end{array}$ & $\begin{array}{c}0.068 \\
(2.25)^{*}\end{array}$ & $\begin{array}{l}0.091 \\
(2.39)^{*}\end{array}$ \\
\hline Adjusted $R^{2}$ & 0.680 & 0.691 & 0.323 & 0.391 & 0.445 & 0.612 & 0.400 \\
\hline \multicolumn{8}{|l|}{ D.W. } \\
\hline $\begin{array}{l}\text { Original } \\
\text { After transformed using Cochrane-Orcutt }\end{array}$ & 1.973 & 1.906 & $\begin{array}{l}1.023 \\
2.114\end{array}$ & $\begin{array}{l}1.175 \\
2.050\end{array}$ & $\begin{array}{l}1.241 \\
2.041\end{array}$ & 2.146 & $\begin{array}{l}1.373 \\
2.178\end{array}$ \\
\hline$\rho$ (AR coefficient for error terms) & & & 0.505 & 0.431 & 0.401 & & 0.322 \\
\hline $\begin{array}{l}\text { Long-run impact of FSI in advanced economies } \\
\text { Long-run impact of FSI in GCC countries }\end{array}$ & 0.279 & $\begin{array}{l}0.188 \\
0.307\end{array}$ & 0.334 & 0.290 & $\begin{array}{l}0.226 \\
0.221\end{array}$ & 0.333 & 0.294 \\
\hline
\end{tabular}

17. Based on Specifications (2) and (5) in Table 1 (those with the greatest explanatory power among the estimated regressions) financial stress in MENA EM countries and GCC countries can be decomposed into four components: (i) direct spillover of financial stress from advanced economies; (ii) indirect spillover of financial stress from advanced economies through GCC countries, ${ }^{4}$ (iii) spillover from financial stress originating in GCC countries, ${ }^{5}$ and (iv) other factors, which include the effects of production activity in advanced economies, oil price developments, commodity price developments and any unexplained developments by the model (Figures 7 and 8). The figures demonstrate that financial stress in advanced economies has directly and indirectly contributed to increased financial stress in MENA EM countries, especially after the Lehman shock (Figure 8).

\footnotetext{
${ }^{4}$ This is given by multiplying (a) the increased financial stress in the EM countries due to the increased financial stress in the GCC countries, derived from the estimated parameters in Table 1 (Specification 2), with (b) the share of increased financial stress in GCC countries due to the increased financial stress in advanced economies in Figure 7, derived from Specification (5) in Table 1.

${ }^{5}$ This is given by subtracting the contribution of increased financial stress in advanced economies through GCC countries (i.e., (ii) in paragraph 16) from the contribution of increased financial stress in GCC countries to that in the EM countries, derived from the estimated parameters in Table 1 (Specification 2).
} 

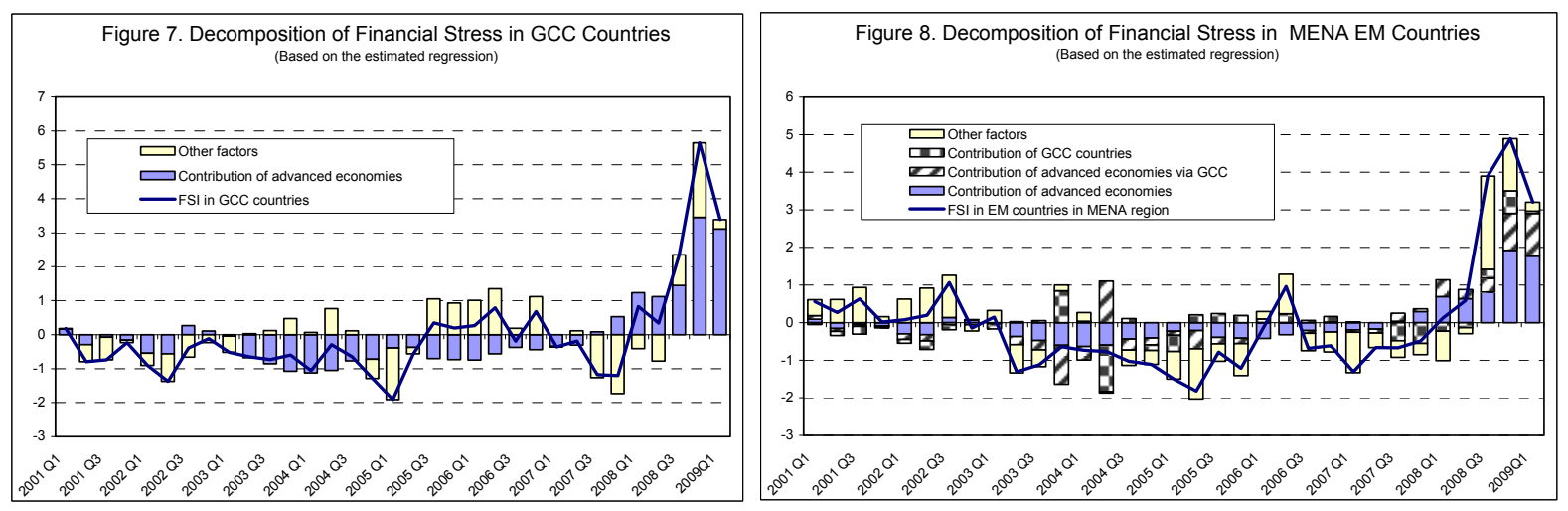

18. Table 2 summarizes the estimated decomposition of financial stress derived from the estimated common timevarying component model in Figure 8, comparing the contribution of each component before and after the Lehman shock. The table shows that financial stress in MENA EM countries increased by over 4 points

Table 2. Financial Stress in MENA EM Countries, Decomposition (Based on the estimated time-varying model)

\begin{tabular}{lccc}
\hline & $\begin{array}{c}\text { 2005-Q3 2008 } \\
\text { Before Lehman }\end{array}$ & $\begin{array}{c}\text { Q4 2008-Q1 2009 } \\
\text { After Lehman }\end{array}$ & Change \\
\hline $\begin{array}{l}\text { Financial stress in EM countries } \\
\text { of which, contribution of }\end{array}$ & -0.3 & 4.0 & 4.3 \\
$\quad$ Advanced economies & 0.0 & 1.8 & 1.9 \\
Advanced economies through GCC & 0.0 & 1.1 & 1.0 \\
GCC other than advanced economies & 0.0 & 0.3 & 0.4 \\
$\quad$ Other factors & -0.3 & 0.8 & 1.1 \\
\hline
\end{tabular}
after the Lehman shock, about 3 points of which was directly or indirectly (through GCC countries) due to increased financial stress in advanced economies. In other words, nearly two-thirds of increased financial stress in MENA EM countries after the Lehman shock is attributable to direct or indirect spillovers of financial stress in advanced economies.

\section{ImPact of Financial Stress and Trade Partners' Economic ACtivity to ECONOMIC ACTIVITY IN EM COUNTRIES IN THE MENA REGION-PANEL GMM ANALYSIS}

19. This section empirically investigates the impact of increased financial stress - closely related to financial stress in advanced economies as demonstrated in the previous sectionand slowdown in trade partners' economic activity on economic activity in five MENA EM countries: both are regarded as typical "external" shocks to the countries in the sample, where Lebanon is excluded from the original sample because of limited data availability. The impact is explored by estimating the following baseline model (quarterly data) spanning from the first quarter of 2001 to the first quarter of 2009 :

$$
g_{i t}^{y}=\alpha_{i}+\beta g_{i t-1}^{y}+\gamma F S I_{i t}+\delta g_{i t}^{T r}+\sum_{k} \phi_{k} X_{i t}^{k}+\varepsilon_{i t}
$$

where $g_{i t}^{y}$ is real GDP growth (year-over-year) in MENA EM country $i$ at period $t, F S I_{i t}$ is financial stress of country $i$ at period $t, g_{i t}^{T r}$ real GDP growth (year-over-year) of trade 
partners of country $i$ at period $t$, and $X_{i t}$ is a vector of control variables (year-over-year oil prices change and commodity prices change).

20. The model captures the main features of the spillovers of the financial crisis in advanced economies to emerging market economies. Crises in advanced economies can affect emerging economies through (i) a collapse in export demands for goods and services, (ii) a decline in remittances inflows, and (iii) a sudden stop of capital inflows (foreign direct investment, portfolio inflows and bank loans). Whereas the first route is proxied by economic activity in trade partners, the FSI can somewhat capture the second and third routes. For example, any sharp change in remittances should be somewhat translated into a change in EMPI since remittances are generally used to finance trade and service account deficits; and any dramatic change in capital inflows should be associated with sharp changes in stock prices, international reserves, sovereign spreads and exchange rate. Accordingly, economic theory suggests that the estimated coefficients for financial stress and trade partners' GDP growth in the model are negative and positive, respectively.

21. Since a lag of real GDP growth is included in the right hand side of the model, a usual fixed effect panel regression does not give consistent estimators, suggesting that the regression must be estimated by the Generalized Method of Moments (GMM), ${ }^{6}$ where lags of regressors other than real GDP growth, financial stress in advanced economies, and time dummies are used as instrumental variables (see Appendix III). Furthermore, as alternatives, regressions including a lag of financial stress and trade partners' real GDP growth are estimated.

\footnotetext{
${ }^{6}$ See Baltagi (2005).
} 
Table 3. Estimated Impact of Financial Stress and Trade Partners' Growth on Real GDP Growth in MENA EM Countries ${ }^{1 / 21}$

(Estimates based on Panel GMM)

\begin{tabular}{|c|c|c|c|c|}
\hline Specification & (1) & (2) & (3) & $(4)$ \\
\hline GDP growth $(-1)$ & $\begin{array}{c}0.651 \\
(18.91)^{\star *}\end{array}$ & $\begin{array}{c}0.650 \\
(19.32)^{\star *}\end{array}$ & $\begin{array}{c}0.645 \\
(19.74)^{\star *}\end{array}$ & $\begin{array}{c}0.640 \\
(19.67)^{\star *}\end{array}$ \\
\hline FSI & $\begin{array}{c}-0.091 \\
(-2.54)^{*}\end{array}$ & $\begin{array}{l}-0.045 \\
(-1.00)\end{array}$ & $\begin{array}{c}-0.094 \\
(-2.62)^{\star *}\end{array}$ & $\begin{array}{l}-0.047 \\
(-1.08)\end{array}$ \\
\hline FSI (-1) & & $\begin{array}{c}-0.080 \\
(-2.59)^{\star \star}\end{array}$ & & $\begin{array}{c}-0.084 \\
(-2.69)^{\star \star}\end{array}$ \\
\hline Trade partners' GDP growth & $\begin{array}{c}0.179 \\
(4.86)^{\star *}\end{array}$ & $\begin{array}{c}0.179 \\
(5.02)^{* *}\end{array}$ & $\begin{array}{c}0.147 \\
(2.93)^{* *}\end{array}$ & $\begin{array}{c}0.129 \\
(2.82)^{\star *}\end{array}$ \\
\hline Trade partners' GDP growth (-1) & & & $\begin{array}{l}0.037 \\
(1.64)\end{array}$ & $\begin{array}{c}0.058 \\
(2.18)^{\star}\end{array}$ \\
\hline Oil prices & $\begin{array}{l}-0.008 \\
(-0.35)\end{array}$ & $\begin{array}{l}-0.059 \\
(-0.27)\end{array}$ & $\begin{array}{l}-0.009 \\
(-0.39)\end{array}$ & $\begin{array}{l}-0.008 \\
(-0.34)\end{array}$ \\
\hline Commodity prices & $\begin{array}{l}0.025 \\
(0.74)\end{array}$ & $\begin{array}{l}0.020 \\
(0.62)\end{array}$ & $\begin{array}{l}0.027 \\
(0.78)\end{array}$ & $\begin{array}{l}0.023 \\
(0.68)\end{array}$ \\
\hline Arellano-Bond test for $A R(1)$ & 0.046 & 0.044 & 0.047 & 0.045 \\
\hline Arellano-Bond test for $A R(2)$ & 0.417 & 0.519 & 0.429 & 0.544 \\
\hline Sargan test of overidentification & 0.400 & 0.331 & 0.363 & 0.288 \\
\hline Hansen test for overidentification & 1.000 & 1.000 & 1.000 & 1.000 \\
\hline \multicolumn{5}{|c|}{ Estimated long-run responses of GDP growth to } \\
\hline FSI & -0.26 & -0.36 & -0.26 & -0.36 \\
\hline Trade partners' economic growth & 0.51 & 0.51 & 0.52 & 0.52 \\
\hline
\end{tabular}

${ }^{1 /}$ Egypt, Jordan, Morocco, Pakistan and Tunisia.

${ }^{2 /}$ Number in parenthesis is t-statistics. ${ }^{* *}$ and ${ }^{*}$ indicate statistically significant at 1 percent level and 5 percent level, respectively.

22. The results of the Generalized Method of Moments (GMM) estimates are summarized in Table $3:{ }^{7}$

\footnotetext{
${ }^{7}$ Table 3 reports the regressions with only one endogenous variable: a lag of real GDP growth. The model may have, however, another (other) endogenous variable(s): financial stress (and its lag). An alternative specification assuming that FSI is endogenous also passed all tests for overidentification and endogeneity, with similar estimated parameters reported in Table 3. This result is also consistent with the discussion in Section III, namely that the increased financial stress in advanced economies has affected financial stress in MENA EM countries.
} 
- $\quad$ Both estimated coefficients for financial stress and trade partners' real GDP growth are statistically significant and have signs consistent with economic theory in all specifications;

- A 1 percentage point permanent increase in financial stress and decline in trade partners' real GDP growth would reduce real GDP growth in MENA EM countries by about 0.3 percentage points and 0.5 percentage points, respectively; and

- $\quad$ Financial stress with one quarter lag affects real GDP growth more strongly than does contemporary financial stress, reflecting perhaps the impact of stress on investment. This logic is in line with a common observation that firms need some time to adjust their investment activity against exogenous shocks (Specifications (2) and (4)).

23. Using the estimated GMM parameters of Specification (4) in Table 3 and the decomposition of financial stress in MENA EM countries presented in the previous section (Figure 8), real GDP growth can be decomposed into four elements: trade partners' real GDP growth; financial stress from advanced economies and GCC countries; financial stress from countries other than the advanced economies and GCC countries; and other

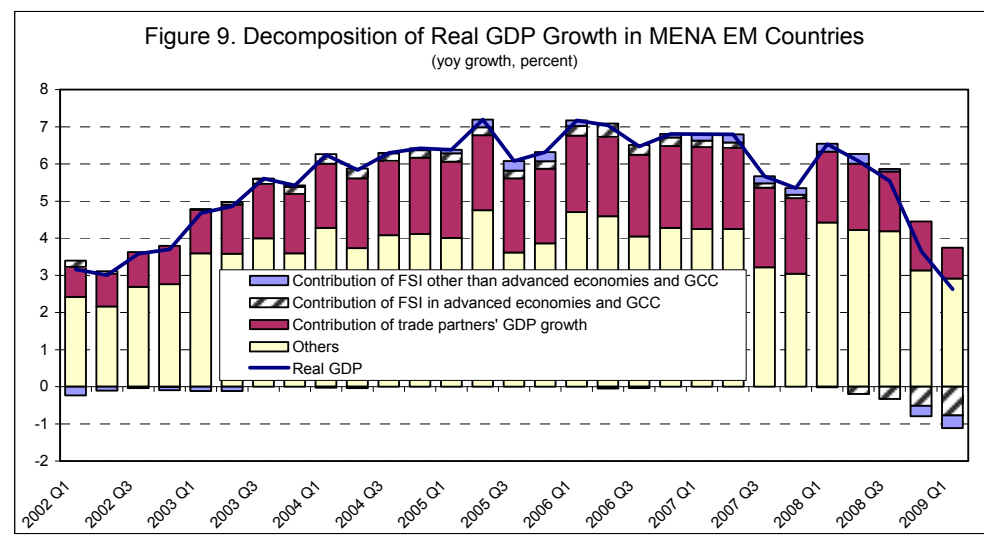
factors-mainly reflecting domestic factors of potential GDP growth. Figure 9 demonstrates that:

- $\quad$ The contribution of trade partners' real GDP growth declined sharply during the last two quarters (Q4 2008 and Q1 2009);

- $\quad$ The contribution of financial stress, especially financial stress from advanced economies and GCC countries, was negative during the last two quarters; whereas,

- The contribution of other factors did not show a substantial decline compared to its historical value.

The above three observations are in line with intuition: the recent sharp decline in economic activity in MENA EM countries was due to spillovers of the global crisis. 
24. Table 4 simplifies the estimated decomposition shown in Figure 9, comparing real GDP growth during Q4 2008 and Q1 2009 with its average during 2005-Q3 2008 - a period of strong economic activity prior to the Lehman shock. According to the estimated GMM, real GDP growth declined by 3.3 percentage points after the shock, 2.2 percentage points of which were due to a slowdown in real GDP

Table 4. Decomposition of Real GDP Growth in MENA EM Countries Before and After the Lehman Shock ${ }^{1 / 2 /}$ (yoy growth, percent and percentage points)

\begin{tabular}{lccc}
\hline & 2005-Q3 2008 & $\begin{array}{c}\text { After Q3 2008 } \\
\text { After Lehman }\end{array}$ & Change \\
\hline Real GDP growth & 6.4 & 3.1 & -3.3 \\
Trade partners' real GDP growth & 2.0 & 1.1 & -1.0 \\
Financial stress & 0.3 & -1.0 & -1.2 \\
Other factors & 4.1 & 3.0 & -1.1 \\
\hline${ }^{1 /}$ Simple average of Egypt, Jordan, Morocco, Pakistan, and Tunisia. & & \\
${ }^{2 /}$ Based on Specification (4) in GMM estimates in Table 3. & & \\
\end{tabular}
growth in trade partners (contribution: 1.0 percentage point) and increased financial stress (contribution: 1.2 percentage points) in the MENA EM countries.

25. Moreover, a simple back-of-the-envelope calculation using the estimated contribution of conditions in advanced economies to (i) increased financial stress in MENA EM countries (0.8 percentage points, from Tables 2 and 4) and to (ii) MENA EM countries' trade partners' real GDP growth $(0.8$ percentage points, derived from combining the results presented in Tables 2 and 4 and Table A-2 in Appendix IV), indicates that increased financial stress and a slowdown in economic activity in advanced economies can explain at least about a half of the drop (i.e., 1.6 percentage points of 3.3 percentage points in Table 2) in real GDP growth in MENA EM countries after the Lehman shock.

\section{COMPARISON OF THE ECONOMIC ACTIVITY IMPLIED BY THE ESTIMATED MODEL WITH THE WEO AND REO PROJECTIONS}

26. Given the estimated model by GMM and trade partners' real GDP growth projections in the Global Economic Environment (GEE), a back-of-envelope calculation with two additional assumptions gives projections of real GDP growth for MENA EM countries, where the two assumptions are:

- $\quad$ Financial stress (averaged over five countries) is expected to gradually decline to -0.5 toward 2011, given (i) that the FSI declined to one in April 2009, (ii) a gradual decline in financial stress in advanced economies as assumed in WEO and (iii) the FSI in MENA EM countries during 2005-2007averaged about -1; and

- The contribution of other factors - mainly related to the domestic component of potential GDP growth - stays between 3 and 4 percent, where (i) 3 percent (floor) is the contribution after the Lehman shock and (ii) 4 percent (ceiling) is the average contribution during the strong economic activity period (2005-Q3 2008) in Table 4. 
27. Table 5 summarizes the results. The contribution of trade partners' economic activity does not return to the 2008 level until 2011. The negative contribution of financial stress shrinks and finally turns positive in 2011. In sum, the estimated model by GMM projects a real GDP growth rate of $2.5-3.5$ percent in $2009,3.5-4.5$ percent in 2010, and 4.5-5.5 percent in 2011. These estimates are similar to the baseline

\begin{tabular}{|c|c|c|c|c|c|}
\hline \multicolumn{6}{|c|}{$\begin{array}{l}\text { Table 5. Real GDP Growth in MENA EM Countries }{ }^{1 /} \\
\text { (Based on the GMM estimates and GEE }{ }^{2 / 3 /} \text {, percent) }\end{array}$} \\
\hline & $\begin{array}{r}2007 \\
\text { Act. }\end{array}$ & $\begin{array}{c}2008 \\
\text { Act. }\end{array}$ & $\begin{array}{l}2009 \\
\text { Proj. }\end{array}$ & $\begin{array}{l}2010 \\
\text { Proj. }\end{array}$ & $\begin{array}{l}2011 \\
\text { Proj. }\end{array}$ \\
\hline Overall real GDP growth & 6.2 & 5.4 & $2.3-3.3$ & $3.4-4.4$ & $4.4-5.4$ \\
\hline Trade partners growth & 2.1 & 1.7 & 0.1 & 0.6 & 1.3 \\
\hline Financial stress ${ }^{4 /}$ & 0.3 & -0.2 & -0.9 & -0.2 & 0.1 \\
\hline Other factors ${ }^{5 /}$ & 3.7 & 4.0 & $3.0-4.0$ & $3.0-4.0$ & $3.0-4.0$ \\
\hline Current WEOREO baseline (beyond 2009) & & & 3.4 & 3.8 & 4.6 \\
\hline \multicolumn{6}{|c|}{$\begin{array}{l}{ }^{1 /} \text { Egypt, Jordan, Morocco, Pakistan, and Tunisia. } \\
{ }^{2 /} \text { Trade partners' contribution is based on GEE. } \\
\text { 3/ Egypt data is adjusted from financial year base to calendar year base. } \\
{ }^{4 /} \text { FSI is assumed to gradually decline to }-0.5 \text { toward } 2011 \text { (April } 2009 \text { actual is about } 1 \text { ), where } \\
\text { average of FSI during } 2005-2007 \text { was about }-1 \text {. }\end{array}$} \\
\hline
\end{tabular}
projections for the five MENA EM countries in the $W E O$ and REO Fall 2009 exercise, which averaged 3.5 percent for 2009, 4 percent for 2010, and 4.5 percent for 2011.

28. The results in Table 5 do not change substantially under more pessimistic or optimistic assumptions of financial stress beyond the second quarter of 2009. For example, even when financial stress stays at the same level as in April 2009 (one), instead of gradually improving to -0.5 toward 2011, projected real GDP growth for both 2010 and 2011 drops by about 0.3 percentage points. Alternatively, if financial stress declines more rapidly than the baseline, i.e., by one point in 2010-2011, real GDP growth increases by about 0.3 percentage points in both years.

29. The presence of negative spillovers in MENA EM countries does not necessarily contradict the fact that the region has been impacted less severely than many others. Authorities in the MENA region have responded to the spillovers with countercyclical policies, and any cross-regional comparison of spillovers would, of course, require a comparison of such policy responses as well - an exercise that is outside the scope of this paper.

\section{Conclusions and Policy Implications}

30. Using the FSI, this paper has empirically investigated spillover effects of the global financial crisis on financial conditions and economic activity in MENA EM countries. Results indicate that nearly two-thirds of increased financial stress in these countries after the Lehman shock is attributable to direct or indirect spillovers of financial stress in advanced economies. In addition, a simple back-of-envelope calculation with the estimated models indicates that increased financial stress and slowdown in economic activity in advanced economies can explain about half of the decline in real GDP growth in MENA EM countries after the Lehman shock. Furthermore, the projections of real GDP growth in the Fall 2009 $W E O$ and $R E O$ exercise are broadly consistent with the projections derived from the estimated models.

31. Estimates of spillover effects are useful in that they can help policymakers determine corrective countercyclical policy measures - such as the extent of fiscal stimulus and size of interest rate cuts - required for maintaining macroeconomic stability and sustaining economic activity. 


\section{APPENDIX I. TECHNICAL DESCRIPTION OF THE FINANCIAL STRESS INDEX (FSI)}

This appendix follows Chapter 4 in IMF (2009a) in describing the components and methodology used to construct the FSI for emerging market economies, which is composed of four market-based price indicators and an exchange market pressure index (EMPI). Each component is de-meaned and normalized by its standard deviation, and then added together to construct the index. Normalizing each component by its standard deviation is necessary to ensure that the overall index is not dominated by large fluctuations in one component. The additive feature of the index allows for a straightforward decomposition into contributions of each component.

The FSI is given by the sum of the five components: the EMPI, sovereign spreads, the "banking sector" $\beta$ (beta), stock returns, and time-varying stock return volatility:

$$
F S I=E M P I+\text { Sovereign spreads }+ \text { "banking sector" } \beta+\text { Stock returns }+ \text { Stock volatility, }
$$

where:

(i) an EMPI increases as exchange rate depreciates or as international reserves decline, where the EMPI for month $t$ is given by the following formula:

$$
E M P I_{t}=\frac{\Delta e_{t}-\mu_{\Delta e}}{\sigma_{\Delta e}}-\frac{\left(\Delta R E S_{t}-\mu_{\Delta R E S}\right)}{\sigma_{\Delta R E S}} .
$$

$\triangle e$ and $\triangle R E S$ are the month-over-month percent changes in the nominal exchange rate vis-à-vis an anchor currency (for example, US dollar or Euro) and total reserves minus gold, respectively. $\mu$ and $\sigma$ denote the mean and standard deviation of the relevant series, respectively, over the sample period;

(ii) rising sovereign spreads indicates increased (external) default risk of an country, where the spreads are computed using the reported spreads (for example, JP Morgan EMBI Global spreads or Credit Default Swap $<$ CDS $>$ spreads), and defined as the bond yield minus 10-year US treasury yield;

(iii) the "banking sector" $\beta$ (beta) is derived from the standard capital asset pricing model $\left(\mathrm{CAPM}^{8}\right)$ :

$$
\beta_{t}=\frac{\operatorname{Cov}\left(r_{t}^{M}, r_{t}^{B}\right)}{\sigma_{M}^{2}},
$$

where $r$ represents the year-over-year banking or market returns, computed over a 12-month rolling window. A $\beta$ larger than one-indicating that banking sector stocks are moving more than proportionately with the overall stock market—suggests that the banking sector is relatively risky and is associated with a higher likelihood of a banking crisis. As in Chapter 4 in IMF (2009a), the banking $\beta$ records its value only when banking returns were lower than overall market returns, intending to better capture banking-related financial stress;

\footnotetext{
${ }^{8}$ Chapter 10 in Blanchard and Fischer (1989) provides basic explanation on the CAPM.
} 
(iv) stock price returns are a proxy to capture that falling equity prices correspond to increased market stress, where the returns are the month-over-month real change in the stock index multiplied by -1 , so that a decline in equity prices corresponds to increased securities market related stress; and

(v) time-varying stock returns volatility represents financial uncertainty, higher volatility captures heightened uncertainty in an economy, derived from a GARCH $(1,1)$ specification, using month-over-month real returns modeled as an autoregressive process with 12 lags. 


\section{APPENDIX II. DATA SOURCES}

The FSI for 12 MENA countries, ${ }^{9}$ covering January 2001 to March 2009, is estimated following the methodology in Chapter 4 of IMF (2009a). Data for the nominal exchange rate and international reserves are taken from the International Financial Statistics (IFS). Sovereign spreads are based on JP Morgan EMBI Global spreads (if available) or CDS spreads in Markit and Bloomberg. ${ }^{10}$ Stock price returns are based on stock market indices of each country, taken from Bloomberg. Stock price returns in banking sector required to compute the "banking sector" $\beta$ are computed from (i) banking sector indices (if available) or otherwise (ii) the median of the stock price returns (year-over-year) of individual banks, both from Bloomberg. ${ }^{11}$

The FSI for advanced economies, covering January 2001 to March 2009, is given as the weighted average of the FSIs of 17 advanced countries ${ }^{12}$ estimated by the IMF's Research Department (Cardarelli et al. 2009), weighted by GDP (PPP base), taken from WEO. Monthly production in advanced economies is also given as a weighted average of the monthly production index of 17 advanced countries taken from the IFS, weighted by GDP (PPP).

For Egypt, Jordan, Morocco, and Tunisia, quarterly real GDP growth (year-over-year) is estimated from official quarterly GDP data spanning the first quarter of 2001 to the first quarter of 2009. For Pakistan, given the lack of official data, quarterly real GDP data is taken from the series estimated by Kemal and Arby (2004) through 2003 and extended by the author after that following their method. Real GDP growth (year-over-year) of trade partners of each country (trade weighted, quarterly basis) is taken from Global Economic Environment (GEE) in the World Economic Outlook (WEO) database. Commodity prices, including oil prices, are taken from the Global Assumption (GAS) in the WEO database.

\footnotetext{
${ }^{9}$ Six emerging market (EM) countries (Egypt, Jordan, Lebanon, Morocco, Pakistan, and Tunisia) and six GCC countries (Bahrain, Kuwait, Oman, Qatar, Saudi Arabia, and the United Arab Emirates).

${ }^{10}$ Spreads data for Kuwait and Oman are not available. Spreads data for Qatar, Saudi Arabia, Tunisia, and the United Arab Emirates are available after June 2003, June 2004, May 2002, and February 2007, respectively.

${ }^{11}$ Banking sector $\beta$ for Qatar and the United Arab Emirates is available only after July 2004 and June 2002, respectively.

${ }^{12}$ Austria, Australia, Belgium, Canada, Denmark, Germany, Finland, France, Italy, Japan, Netherlands, Norway, Spain, Sweden, Switzerland, United Kingdom, and United States.
} 


\section{APPENDiX III. PANEl GMM Estimators}

Suppose that the estimated regression is specified as follows:

$$
y_{i t}=\alpha_{i}+\beta y_{i t-1}+X_{i t} \gamma+\varepsilon_{i t}
$$

where $y_{i t}$ is the dependent variable (real GDP growth in the text) for country $i$ at time $t ; X_{i t}$ is a vector of variables as specified in the text; and $\alpha_{i}$ is the country fixed effect. Equation (A1) is differenced to get rid of the country fixed effect effects and the instruments used are lagged levels of regressors:

$$
y_{i t}-y_{i t-1}=\beta\left(y_{i t}-y_{i t-1}\right)+\left(X_{i t}-X_{i t-1}\right) \gamma+\varepsilon_{i t}-\varepsilon_{i t-1}
$$

The moment conditions arising from equation (A2) are:

$$
E\left[\left(\varepsilon_{i t}-\varepsilon_{i t-1}\right) z_{i t-1}\right]=0
$$

where $z_{i t-1}$ is the vector of instrumental variables - including lagged levels of regressors. The estimator based on (A3) is the GMM (Generalized Method of Moments)-Diff. The GMMSys estimator, which is used as main estimator in the paper, uses additional moment conditions in addition to the moment conditions in (A3). These are equations in levels (equation A1) but with a weaker assumption than that the country fixed effects are uncorrelated with differenced regressors (which amounts to a restriction on initial conditions):

$$
E\left[\left(\alpha_{i}+\varepsilon_{i t}\right) \Delta z_{i t-1}\right]=0
$$

Now, the equation is specified in levels but the instruments, which are lagged levels of regressors, are differenced. 


\section{ApPendix IV. Relation Between Economic ACtivity in Trade Partners OF MENA EM COUNTRIES AND ADVANCED ECONOMIES-COMMON TIME-VARYING COMPONENT ANALYSIS}

This appendix uses the common time-varying component method used in the text (Section III) to verify relation between economic activity in trade partners of MENA EM countries in the MENA region and that in advanced economies. ${ }^{13}$ As in Section III, quarterly panel data of real GDP growth (yearover-year) for MENA EM countries is regressed on countryspecific fixed effects and time dummies. After that, the estimated time series of coefficientrepresenting the common time-varying

\begin{tabular}{|c|c|c|}
\hline \multicolumn{3}{|c|}{$\begin{array}{c}\text { Table A-1. Determinants of Common Time Trend } \\
\text { in Trade Partners' Economic Activity }{ }^{1 / 2 /}\end{array}$} \\
\hline Real GDP growth in advanced economies & $\begin{array}{l}0.499 \\
(4.50)\end{array}$ & \\
\hline Real GDP growth in G7 countries & & $\begin{array}{l}0.533 \\
(3.97)\end{array}$ \\
\hline Adjusted $R^{2}$ & 0.309 & 0.330 \\
\hline \multicolumn{3}{|l|}{ D.W. } \\
\hline Original & 0.465 & 0.472 \\
\hline After transformed using Cochrane-Orcutt & 1.879 & 1.946 \\
\hline$\rho$ (AR coefficient for error terms) & 0.782 & 0.779 \\
\hline $\begin{array}{l}{ }^{1 /} \text { Number in parenthesis is t-statistics. } \\
{ }^{2 /} \text { Egypt, Jordan, Lebanon, Morocco, Pakistan, and T }\end{array}$ & & \\
\hline
\end{tabular}
component in economic activity in MENA EM countries - is regressed on real GDP growth (year-over-year) in advanced economies. As an alternative, real GDP growth in advanced economies is replaced by that in the G7, in an attempt to check the robustness of the estimated parameters. The results based on the Cochrane-Orcutt AR(1) regression are summarized in Table A-1. Real GDP growth in trade partners has a statistically significant correlation with economic activity in MENA EM countries.

The estimated contribution of real GDP in advanced economies to economic activity in the trade partners of MENA EM countries suggests that nearly threequarters of a drop in trade partners' growth after the Lehman shock was due to a slowdown in economic activity in advanced economies, as presented in Table A-2.

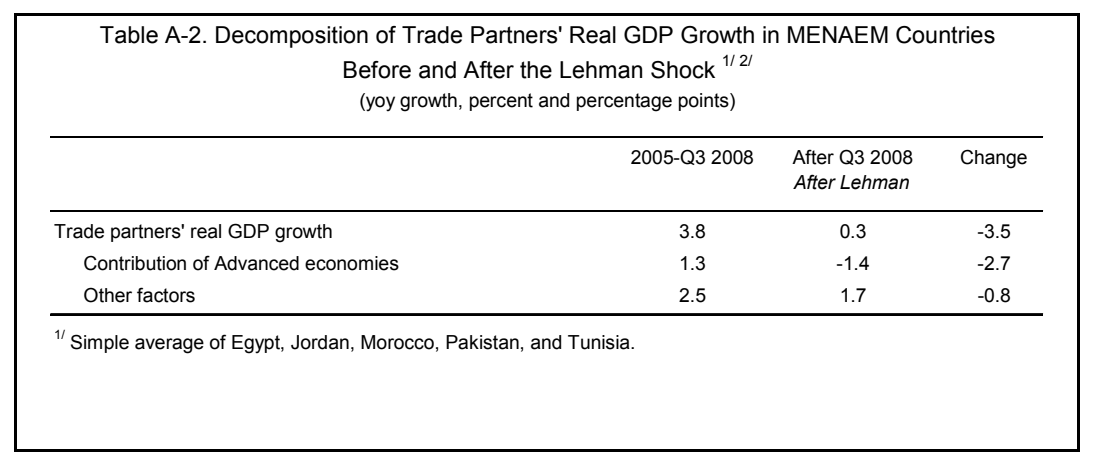

\footnotetext{
${ }^{13}$ Based on WEO definition instead of 17 countries demonstrated in Appendix II.
} 


\section{REFERENCES}

Baltagi, Badi H., 2005, Econometric Analysis of Panel Data, Third edition, John Wiley \& Suns (West Sussex: England).

Beirne et al., 2008, "Volatility Spillovers and Contagion from Mature to Emerging Stock Markets,” IMF Working Paper No. 08/286 (Washington: International Monetary Fund).

Blanchard, Oliver and Stanley Fischer, 1989, Lectures on Macroeconomic (Cambridge, Massachusetts: MIT Press).

Cardarelli, Elekdag, and Lall, 2009, "Financial Stress, Downturns and Recovery," IMF Working Paper No. 09/100 (Washington: International Monetary Fund).

Frank, Nathaniel and Heiko Hesse, 2009, "Financial Spillovers to Emerging Markets During the Global Financial Crisis," IMF Working Paper No. 09/104 (Washington: International Monetary Fund).

Galesi, Alessandro and Silvia Sgherri, 2009, "Regional Financial Spillovers Across Europe: A Global VAR Analysis," IMF Working Paper No. 09/23 (Washington: International Monetary Fund).

Ghosh et al., 2009, "Coping with the Crisis: Policy Options for Emerging Market Countries," IMF Staff Position Note No. 09/08 (Washington: International Monetary Fund).

International Monetary Fund, 2009, World Economic Outlook, Spring 2009 (Washington).

Kemal, A. R. and Muhammad Farooq Arby, 2004, "Quarterisation of Annual GDP of Pakistan,” Statistical Paper Series No. 5 (Islamabad: Pakistan Institution of Development Economics).

Mühleisen et al., 2008, Who's Driving Whom? Analyzing External and Intra-Regional Linkages in the Americas (Washington: International Monetary Fund). 